\title{
Invited review: Heat stress effects during late gestation on dry cows and their calves
}

\author{
S. Tao and G. E. Dahl ${ }^{1}$ \\ Department of Animal Sciences, University of Florida, Gainesville 32611
}

\begin{abstract}
In dairy cattle, late gestation is a critical period for fetal growth and physiological transition into the next lactation. Environmental factors, such as temperature and light, exert dramatic effects on the production, health, and well-being of animals during this period and after parturition. The aim of this review was to introduce effects of heat stress during late gestation on dairy cattle, and discuss the biological mechanisms that underlie the observed production and health responses in the dam and her fetus. Relative to cooled cows, cows that are heat stressed during late gestation have impaired mammary growth before parturition and decreased milk production in the subsequent lactation. In response to higher milk yield, cows cooled prepartum undergo a series of homeorhetic adaptations in early lactation to meet higher demand for milk synthesis compared with heat-stressed cows, but no direct effect of environmental heat stress on metabolism exists during the dry period. Prepartum cooling improves immune status of transition cows and evidence suggests that altered prolactin signaling in immune cells mediates the effects of heat stress on immune function. Late-gestation heat stress compromises placental development, which results in fetal hypoxia, malnutrition, and eventually fetal growth retardation. Maternal heat stress may also have carryover effects on the postnatal growth of offspring, but direct evidence is still lacking. Emerging evidence suggests that offspring from prepartum heat-stressed cows have compromised passive immunity and impaired cell-mediated immune function compared with those from cooled cows.
\end{abstract}

Key words: heat stress, late gestation, lactation, fetus

\section{INTRODUCTION}

Late gestation is a critical period in the production cycle of food animals. In dairy cattle, for example, the fetus grows at the fastest rate and accumulates ap-

Received October 17, 2012.

Accepted March 19, 2013.

${ }^{1}$ Corresponding author: gdahl@ufl.edu proximately $60 \%$ of its birth weight during the last 2 mo of gestation (Bauman and Currie, 1980). The dry period or nonlactating interval before parturition in dairy cows is also of importance, as extensive mammary gland growth and cell turnover occur before parturition and influence future milk production (Capuco et al., 1997; Sorensen et al., 2006). In the absence of a dry period, dairy cattle produce significantly less milk in the next lactation (Bachman and Schairer, 2003; Grummer and Rastani, 2004). Moreover, the transition period from late gestation to early lactation is characterized by immune dysfunction (Mallard et al., 1998), negative energy balance (Goff and Horst, 1997; Drackley, 1999), and increased incidence of health and metabolic disorders (Goff and Horst, 1997; Mallard et al., 1998). Given the physiological challenges cows experience under the best of conditions, management of external factors are critical to additional negative influences on the cow during this period.

Environmental factors, such as light and temperature, exert dramatic effects on the cow during the dry period (Dahl and Petitclerc, 2003; Collier et al., 2006; Bernabucci et al., 2010) and thus can be manipulated and used as management tools to improve animal production, immune competence, metabolism, and overall well-being. The effects of photoperiod during the dry period have been reviewed recently (Dahl et al., 2012); thus, this review will focus on effects of heat stress during late gestation on dairy cattle.

\section{HEAT STRESS EFFECTS DURING LATE GESTATION IN COWS}

One well-recognized environmental factor that limits production of dairy cattle is elevated ambient temperature. It is well described in lactating dairy cows that thermal stress is related to decreased feed intake, altered metabolism, compromised lactational performance, increased disease incidence, and impaired reproductive performance (Fuquay, 1981; Kadzere et al., 2002; West, 2003). Compared with lactating cows, dry cows generate less metabolic heat (West, 2003) and have a higher upper critical temperature (Hahn, 1999). But environmental thermal stress still influences the 
performance of cows during late gestation and negative effects carry over to the next lactation. For example, Figure 1 summarizes the monthly milk production from 2007 to 2010 and the typical ambient temperature within a year at Okeechobee, Florida, the top-ranked county for dairy cows in the state. From May to August, milk production in Florida declines as air temperatures (and relative humidity) rise. This phenomenon can be explained by decreased lactational performance due to chronic thermal stress in lactating dairy cows. However, it is also clear that the lowest or highest monthly milk production in Florida does not coincide with the highest (July and August) or lowest ambient temperature (January). Instead, cows in Florida produce the lowest amount of milk in September and the most milk in March. Thus, a 2-mo lag between milk yield and air temperature appears consistently in the annual pattern. This observation suggests that, in addition to a direct effect on milk production during lactation, the thermal status of dry cows has a carryover effect on performance in the subsequent lactation. Indeed, cows exposed to heat stress during the dry period have decreased milk production in the next lactation (Wolfenson et al., 1988; do Amaral et al., 2009). In addition to the residual effects on milk production in the next lactation, thermal status of dry cows also affects immune and metabolic function of cows and alters fetal growth and postnatal calf development. Studies comparing the response of heat-stressed and thermoneutral dry cows under controlled environmental chamber conditions are lacking. Thus, the knowledge discussed in current review is extracted from experiments that compare heat-stressed cows and cows under heat stress abatement during the dry period. It is important to mention that cooling applied in those studies does not completely eliminate heat strain on the cows but it is a realistic way to study the biology of heat stress and a feasible intervention under normal management conditions. However, if available, studies conducted in tightly control environmental conditions at other stages of the lactation cycle of cows, or in other species will be specifically indicated in the current review.

\section{Late-Gestation Heat Stress Effects on Lactation Performance and Mammary Function}

As summarized in Figure 2, late-gestation heat stress has a profound effect on milk production in the subsequent lactation compared with milk production of cows that are cooled. Under normal management, complete abatement of heat stress during the summer is unlikely; however, a decrease in body temperature by active cooling during the dry period results in significant improvement in milk production in the next lactation. Indeed, regression analysis of published data from heat-stressed and cooled cows during late gestation reveals a significant correlation between afternoon rectal temperature in late gestation and milk production in the next lactation (Figure 3). Other factors also affect the effect of prepartum cooling on the milk production in the next lactation. Depending on the method and duration of prepartum cooling, dry dairy cattle have different milk yield responses in the next lactation. With limited cooling, such as shade (Collier et al., 1982b) or short-interval soaking in the middle of the day (Avendaño-Reyes et al., 2006), only modest increases in subsequent milk production were observed and the difference was not statistically significant. However, when more extensive cooling (shade, fans, and sprinklers) was provided to dry cows, milk production in the subsequent lactation was significantly improved (Wolfenson et al., 1988; do Amaral et al., 2011). The duration of prepartum cooling during environmental heat stress may also affect future lactational performance. Moore et al. (1992) studied the relationship between climatological data and milk production of cows that calved from July to September in Mississippi using regression analysis and found that exposure to heat stress during last $30 \mathrm{~d}$ of gestation was too short to elicit any effect on milk production in the next lactation. However, in a controlled study (Urdaz et al., 2006), actively cooled cows in the last $28 \mathrm{~d}$ of gestation had improved milk yield in the first $60 \mathrm{~d}$ of lactation compared with noncooled cows.

Therefore, little question exists that heat stress during the dry period decreases subsequent milk production. Additionally, the lactation curves of prepartum cooled cows are consistently higher than those of heat-stressed cows in the next lactation (do Amaral et al., 2009).

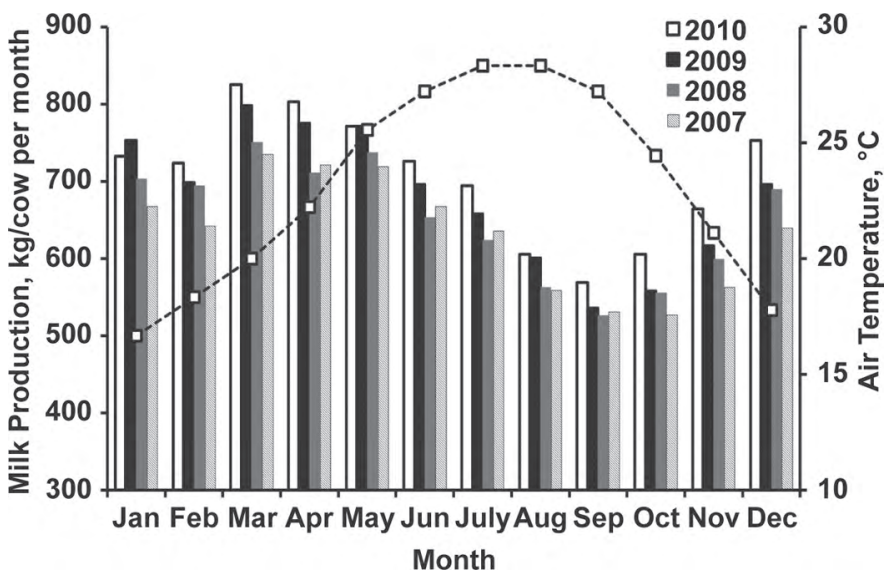

Figure 1. Monthly milk production in Florida (bar graph; data from Florida livestock, dairy, and poultry summary, 2010; USDANASS, 2011) and typical air temperature within a year in Okeechobee, Florida (line graph; data from http://www.weather.com/weather/ wxclimatology/monthly/34972). 


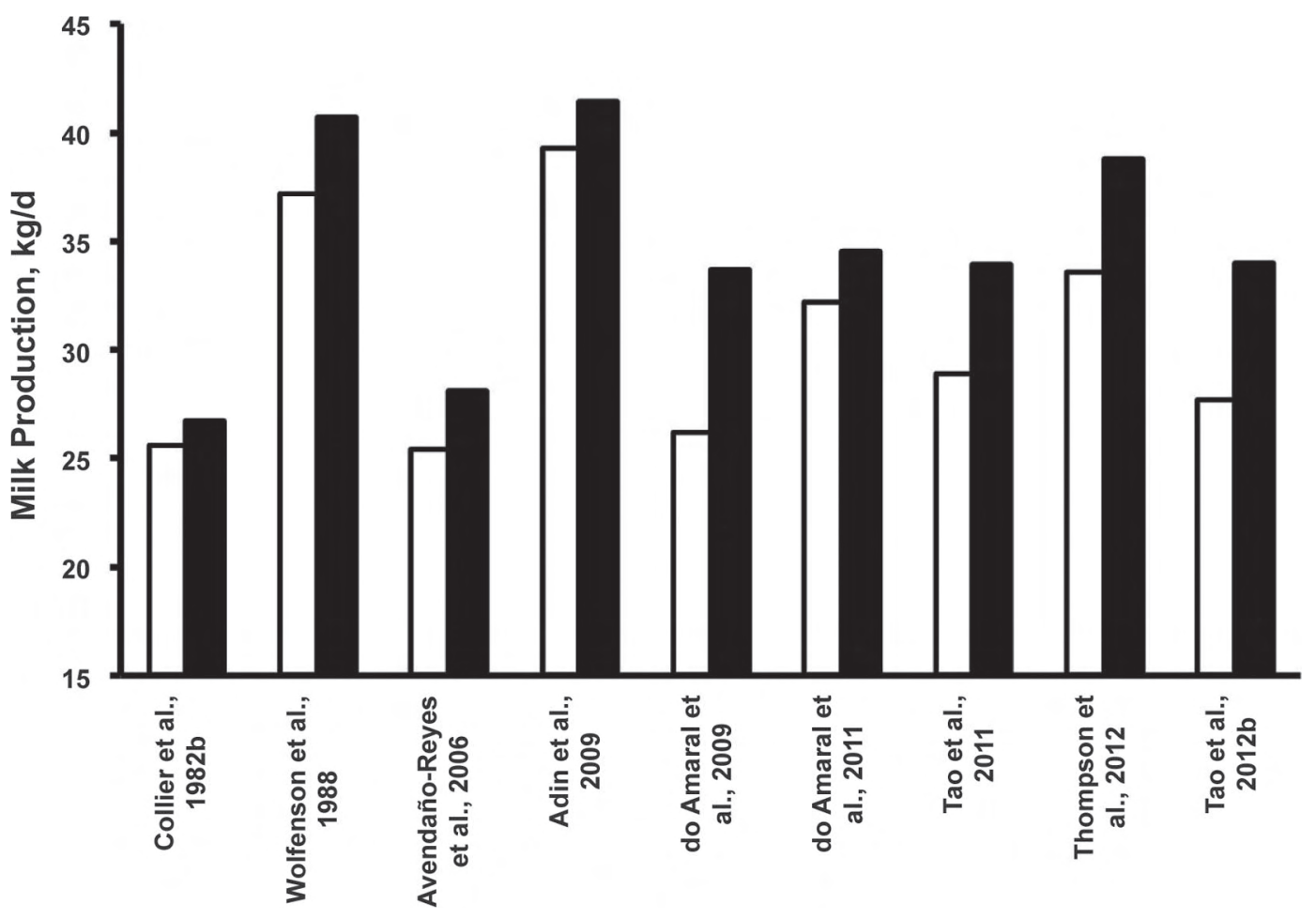

Figure 2. Summary of published studies that examine the effect of heat stress and cooling during the entire dry period on milk production in the subsequent lactation. Open and solid bars represent the daily subsequent milk production $(\mathrm{kg} / \mathrm{d})$ of prepartum heat-stressed and cooled cows, respectively.

Because the lactation curve is ultimately a function of mammary cell number and secretory capacity per cell (Capuco et al., 2003), it is possible that the compromise of subsequent lactational performance under late-gestation heat stress originates from impaired mammary growth during the dry period. To test this hypothesis, in a recent study, cows were randomly assigned to 1 of 2 treatments at dry-off (heat stress or heat stress abatement) and remained on the same treatment until calving (Tao et al., 2011). Mammary biopsies were collected at dry-off and $-20,2$, and $20 \mathrm{~d}$ relative to calving from a subset of animals to evaluate mammary cell proliferation and apoptosis by immunochemistry. Both groups of cows had similar mammary cell apoptosis across the transition period. However, heat-stressed cows had decreased mammary cell proliferation at $-20 \mathrm{~d}$ relative to calving compared with cooled herd mates, but no difference was observed in early lactation when both groups of cows were managed as a single group. These results suggest that prepartum heat-stressed cows have impaired mammary gland development before parturition and less functional mammary cells at the onset of lactation, which then compromises subsequent lactational performance (Tao et al., 2011).

Physiological mechanisms related to compromised mammary gland development during the dry period under heat stress are still not clear, but may include effects on hormone synthesis or exposure. Collier et al. (1982b) postulated that the retarded placental development observed with late-gestation heat stress was

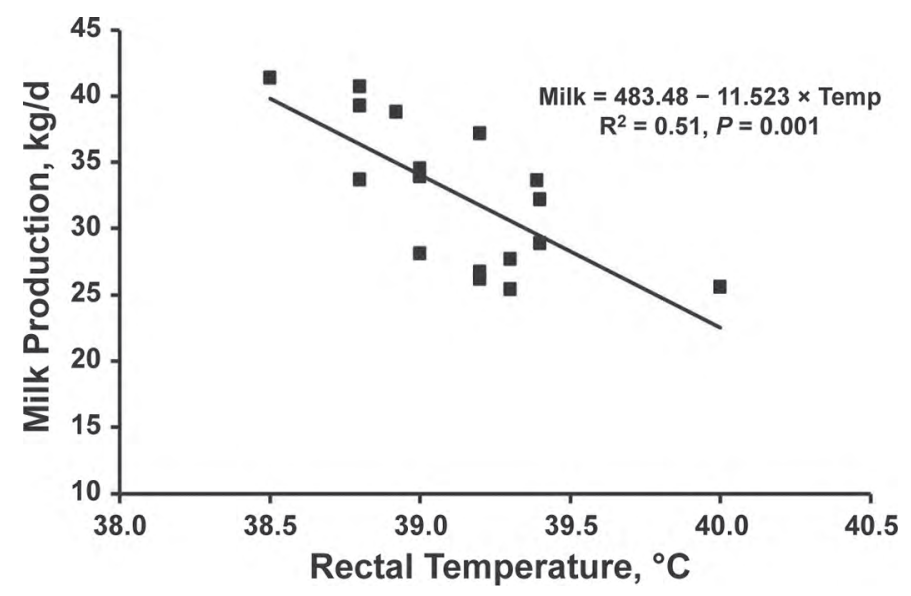

Figure 3. Scatter plot of relationship between afternoon rectal temperature $\left({ }^{\circ} \mathrm{C}\right.$; Temp) of cows during late gestation and daily milk production $(\mathrm{kg} / \mathrm{d})$ in the subsequent lactation. Data were obtained from published papers (Collier et al., 1982b; Wolfenson et al., 1988; Avendaño-Reyes et al., 2006; Adin et al., 2009; do Amaral et al., 2009, 2011; Tao et al., 2011, 2012b; Thompson et al., 2012). Simple regression analysis was performed by PROC GLM of SAS 9.3 (SAS Institute Inc., Cary, NC). 
directly related to impaired mammary function because of the linear relationship between calf birth weight and milk yield of the dam; however, no significant difference in milk production was observed in that study. Therefore, the reduced placental function may not be the only explanation of the significant decrease in milk production following prepartum heat stress observed by others (Wolfenson et al., 1988; do Amaral et al., 2011; Tao et al., 2011). Shorter gestation length is a common outcome of late-gestation heat stress in cows and may also account for the decrease in milk production in the next lactation because it is possible that heat-stressed cows have a more limited period of mammary gland growth while dry. But results from induced parturition studies suggest that a reduction of several days in gestation length only decreases the milk yield in early lactation rather than the entire lactation (Schmitt et al., 1975; Beardsley et al., 1976; Bremmer et al., 1999).

The hormone prolactin (PRL) is integral to mammogenesis and lactogenesis in cattle (Tucker, 2000) and perturbation of PRL physiology during the dry period can affect future milk yield. Indeed, altered PRL signaling induced by variable photoperiod affects mammary gland development during the dry period (Wall et al., 2005) and subsequent milk production (Auchtung et al., 2005). Heat stress in cattle increases circulating concentrations of PRL (Collier et al., 1982a; do Amaral et al., 2009) and an inverse relationship exists between circulating PRL and $P R L R$ gene expression in the liver and lymphocytes (i.e., increased blood PRL concentration coupled with decreased $P R L R$ gene expression) of late-gestation heat-stressed cows (do Amaral et al., 2010, 2011). Additionally, the increased blood estrone sulfate and decreased progesterone concentrations observed in heat-stressed dry cows (Collier et al., 1982b) are also related to decreased PRL signaling in the mammary gland (Tucker, 2000). Therefore, it is reasonable to hypothesize that decreased PRL signaling in the mammary gland occurs in heat-stressed dry cows and exerts some effect to impair subsequent lactational performance (Dahl, 2008).

To test that hypothesis, mammary tissues were collected during the dry period and early lactation (dry-off and $-20,2$, and $20 \mathrm{~d}$ relative to calving) from prepartum cooled or heat-stressed cows (Tao et al., 2011) and mRNA expression of genes involved in PRL signaling and FA synthesis were assessed (Tao et al., 2013). Unexpectedly, no differences existed in expression of genes related to mammary cell function. The similar mRNA expression of genes in FA synthesis between treatments suggests that heat stress during the dry period has no effect on the secretory potential at the individual mammary cell level. In contrast to our hypothesis, the mRNA expression of genes associated with PRL signal- ing was not significantly different between treatments. This observation may suggest that the normal connections between endocrine mediators, such as the positive relationship between circulating estrogen, progesterone, and PRL signaling in mammary tissue (Tucker, 2000), are disrupted by the environmental heat stress. Alternatively, an equally tenable hypothesis is that cellular activity is unaffected by heat stress, but the absolute number of active cells is decreased under heat stress, without any effect on individual cell gene expression. Such an outcome would also be consistent with a sustained influence on the mammary gland (i.e., a persistent improvement in mammary function for that lactation).

Heat stress results in a decrease in mammary blood flow relative to those cows in a thermoneutral environment (Lough et al., 1990), which offers another explanation for the reduced mammary growth during the dry period. Mammary tissue perfusion is critical to support maximum milk production in lactating dairy cows. During the dry period, the mammary gland undergoes extensive growth (Capuco et al., 1997) and is highly metabolic, and so any reduction in mammary blood flow with environmental heat stress may also impede mammary growth. Accelerated mammary cell apoptosis occurs at the beginning of the dry period, but it is still unknown how the enhanced mammary involution affects subsequent lactation. One of the most recognized cellular responses to hyperthermia is the increase in expression of heat shock proteins (HSP), which exert cytoprotective effects on stressed cells as a molecular chaperone to assist folding of newly synthesized proteins and repairing and refolding damaged proteins under challenging conditions (Kregel, 2002) and, therefore, exhibit antiapoptotic properties (Lanneau et al., 2007). In vitro, elevated incubation temperatures induce HSP70 mRNA expression in bovine mammary epithelial cells (Collier et al., 2008). Thus, it is likely that mammary cells of heat-stressed dry cows also have enhanced HSP expression and lower apoptotic capacity at the beginning of the dry period. However, it is not clear if the possible decline in mammary apoptosis under heat stress early in the dry period affects subsequent milk production. One possible approach to investigate the effect of heat stress on involution would involve frequent mammary biopsies during the initial stages of milk stasis and the dry period, and subsequent quantitation and comparison of apoptotic rates in mammary epithelial cells under different environmental conditions.

\section{Late-Gestation Heat Stress Effects on Metabolism}

Similar to that of lactating cows, heat stress during the dry period decreases DMI (Adin et al., 2009; do 
Amaral et al., 2009). As a result of the reduced energy intake, heat-stressed dry cows have lower BW gain in late gestation compared with those under heat stress abatement (Collier et al., 1982a; do Amaral et al., 2009, 2011). Despite the lower feed intake, late-gestation heat stress had no effect on circulating concentrations of glucose (Collier et al., 1982b; do Amaral et al., 2009), NEFA (Urdaz et al., 2006; do Amaral et al., 2009), and insulin (Collier et al., 1982b) before calving relative to cows that were cooled. So, normal physiological boundaries are maintained despite the reduction in intake, suggesting that heat stress does not directly alter nutrient partitioning.

In mid lactation, heat-stressed cows experience negative energy balance and have compromised adipose tissue mobilization, lower circulating NEFA, and enhanced insulin response at peripheral tissues compared with their pair-fed thermoneutral herd mates (Wheelock et al., 2010; Baumgard et al., 2011). Thus, it is possible that the insulin responsiveness at peripheral tissues of dry cows is also altered by heat stress. To test this possibility, a glucose tolerance test (GTT) and an insulin challenge (IC) were performed in heat-stressed and cooled dry cows at $2 \mathrm{wk}$ before parturition (Tao et al., 2012b). In contrast to mid lactation, no differences were observed for glucose or insulin responses during the GTT and IC, which confirms that insulin action at peripheral tissues is not influenced by heat stress during the prepartum period (Tao et al., 2012b). These divergent metabolic responses to heat stress between mid lactation and dry cows may reflect differences in energy status of cows at different stages of the lactation cycle. In mid lactation, heat-stressed cows experience negative energy balance and have a preference to use glucose as the major energetic substrate at peripheral tissues at the expense of milk synthesis. In contrast, the energy and glucose demands for fetal growth of cows in late gestation is much less than that of milk synthesis (Bell, 1995; Drackley et al., 2001; NRC, 2001), and so heat-stressed dry cows may remain in positive energy and glucose balance despite a 10 to $15 \%$ decrease in DMI (Adin et al., 2009; do Amaral et al., 2009; Tao et al., 2011). Therefore, the observed metabolic responses of cows under heat stress in mid lactation do not occur in late gestation (Tao et al., 2012b). Consistent with this interpretation, when exposed to heat stress, cows in late lactation have similar blood NEFA levels compared with those under heat stress abatement (TarazónHerrera et al., 1999) and stay in positive energy balance (Kim et al., 2010). However, data comparing the effect of environmental heat stress on insulin responses at peripheral tissues in early- and late-lactation cows are not available.
Beyond greater energy intake, cooling heat-stressed dry cows offers no other improvement on postabsorptive metabolism before calving. But, thermal status of cattle during the dry period has dramatic carryover effects on metabolic responses in early lactation. As discussed previously, cooling during the dry period improves mammary growth before parturition and enhances subsequent lactational performance (Tao et al., 2011). To meet the energy requirements of the higher milk synthesis demand, prepartum cooled cows require greater energy intake in lactation compared with heatstressed cows. Yet, the difference in DMI postpartum between cooled and heat-stressed dry cows was only observed after a 2- to 4-wk lag postpartum (Tao et al., $2011,2012 b)$. In other words, during the first several weeks of lactation, prepartum cooled cows produce more milk but consume the same amount of feed compared with heat-stressed cows. To cope with the greater deficit between energy input, such as DMI, and output in the form of milk production, prepartum cooled cows use a series of metabolic adaptations in early lactation. Compared with heat-stressed cows, prepartum cooled cows lose more body condition and have increased circulating NEFA and BHBA and lower glucose concentrations in early lactation (do Amaral et al., 2009; Tao et al., 2012b). That altered profile of blood metabolites suggests more active adipose tissue mobilization and greater nutrient demand for milk synthesis of cooled cows (Bauman and Currie, 1980; Vernon and Pond, 1997). Relative to samples from heat-stressed cows, do Amaral et al. (2009) reported that milk fat and hepatic tissue of prepartum cooled cows contained higher proportions of preformed FA in early lactation, which also reflects more extensive body fat mobilization and, thus, higher circulating NEFA in cooled cows. In early lactation, prepartum cooled cows also have lower blood insulin concentration relative to noncooled cows, which is consistent with higher circulating NEFA because insulin enhances lipogenesis and is a potent antilipolytic factor (Bell, 1995; Hayirli, 2006). Additionally, the lower circulating insulin also indicates that cooled cows have greater insulin resistance at the systematic level in early lactation, relative to the heat-stressed cows (Kahn, 1978).

The metabolic adaptations of prepartum cooled cows also occur at the tissue level. Tao et al. (2012b) performed GTT and IC in prepartum cooled and heatstressed cows at 7 and $28 \mathrm{~d}$ postpartum and found that cooled cows had slower glucose clearance during the GTT and reduced glucose response to IC compared with noncooled cows at 7 but not $28 \mathrm{~d}$ postpartum. But no differences in insulin response to GTT or IC were found at either 7 or $28 \mathrm{~d}$ postpartum. These re- 
sults indicate that thermal status during the dry period has no effect on pancreatic sensitivity to glucose and systematic insulin degradation in early lactation; however, at $7 \mathrm{~d}$ postpartum, cooled cows experienced lower insulin response at peripheral tissues relative to noncooled cows, a mechanism to spare glucose for the mammary gland in support of greater milk synthesis. The fact that both groups of cows had similar insulin response at peripheral tissue at $28 \mathrm{~d}$ postpartum may reflect that the greater insulin resistance in cooled cows was overcome by increased DMI as lactation advanced (Tao et al., 2012b). However, the question remains as to whether muscle tissue has a similar adaptive response as adipose tissue in early lactation. For example, it is unclear if both muscle and adipose tissue are all insulin insensitive or just one tissue is responsible for the greater peripheral insulin resistance observed in prepartum cooled cows at $7 \mathrm{~d}$ postpartum.

Increases in adipose tissue mobilization and insulin resistance are the homeorhetic adaptations that prepartum cooled cows use in early lactation to meet the demands of greater milk synthesis compared with heat-stressed cows. Growth hormone $(\mathbf{G H})$ is a major homeorhetic signal that enhances FA mobilization from adipose tissue and alters nutrient partitioning by increasing insulin resistance during the transition period (Etherton and Bauman, 1998; Bauman, 2000). With the similar adipose tissue and insulin responses in early lactation, it appears that homeorhetic responses observed in cooled cows are mediated by the enhanced GH effects. The observation that hepatic suppressors of cytokine signaling 3 gene expression of prepartum cooled cows is increased in early lactation compared with heat-stressed cows (do Amaral et al., 2011) also agrees with the higher GH concentrations because somatotropin administration dramatically increases hepatic suppressors of cytokine signaling $3 \mathrm{mRNA}$ abundance in mid-lactation cows (Rhoads et al., 2010). Prolactin also plays a role in homeorhetic adaptation (Bauman, 2000) and is affected by heat stress (Collier et al., 1982b; do Amaral et al., 2009). Prepartum cooled cows have higher hepatic $P R L R$ gene expression in the transition period compared with heat-stressed cows and the modulated PRL signaling during the transition period is also a possible modulator of homeorhetic responses (do Amaral et al., 2011).

\section{Late-Gestation Heat Stress Effects on Health and Immune Function}

In addition to the compromised lactational performance and altered metabolism, late-gestation heat stress influences animal health and immune function during the transition period. Few studies have explored the relationship between heat stress during late gestation and the incidence of disease postpartum. Urdaz et al. (2006) reported that, compared with heat-stressed cows, those under evaporative cooling during the last $28 \mathrm{~d}$ of gestation had similar incidence of common postpartum health disorders (i.e., displaced abomasum, retained placenta, metritis, and milk fever) in the first 60 DIM. However, in a larger-scale study that included more than 2,600 calving records over 3 consecutive years on a commercial dairy located in Florida, Thompson and Dahl (2012) studied effects of season of the dry period on the occurrence of health disorders in the first 60 DIM, and found that cows dried off in hot months (June, July, and August) had higher incidence of mastitis, respiratory problems, and retained fetal membranes in early lactation compared with those dried in cool months (December, January, and February). Because day length during the hot months $(\sim 14 \mathrm{~h})$ is longer than cool months $(\sim 11 \mathrm{~h})$ in Florida, photoperiod may contribute to the observed increase in disease incidence and cannot be excluded, as exposure to short day length during the dry period is related to the enhanced immune function (Auchtung et al., 2004b). Although the results presented by Thompson and Dahl (2012) are confounded with the seasonal effects during early lactation, the compromised immune function during the transition period due to late-gestation heat stress may partly result in the observation of an increased occurrence of health disorders in early lactation of cows dried off in hot weather.

The immune system includes the nonspecific innate immune function that is the first line of defense to pathogens in the body and the specific adaptive immune function that generates memory of pathogen exposure. Both arms of the immune system are affected by late-gestation heat stress in cattle. To study innate immunity, do Amaral et al. (2011) evaluated the ability of neutrophils to phagocytize and destroy pathogens via oxidative burst from peripheral blood of prepartum cooled or heat-stressed cows during the transition period. No differences were observed between treatments during the dry period; however, residual effects of lategestation heat stress on neutrophil function were observed in early lactation, such that heat-stressed cows had impaired neutrophil phagocytosis and oxidative burst relative to cooled cows (do Amaral et al., 2011). In contrast, acquired immunity during the transition period is compromised by prepartum heat stress. Relative to those from heat-stressed cows during the dry period, peripheral blood mononuclear cells (PBMC) isolated from cooled cows have improved proliferation and tumor necrosis factor- $\alpha(\mathrm{TNF}-\alpha)$ production in response to a mitogen in vitro during the transition period (do Amaral et al., 2010). Similarly, compared 
with those calving during the cool season, cows calving under severe heat stress in the summer have reduced PBMC proliferation (Lacetera et al., 2005). However, this negative effect of heat stress on cell-mediated immune function may depend on the degree of heat stress, as shown in the study of Lacetera et al. (2002) in which cows that calved in moderate summer heat stress had similar PBMC proliferation relative to those that calved in spring. Humoral immunity is also altered by heat stress. Relative to heat-stressed cows, prepartum cooled cows have greater IgG production against ovalbumin challenge during the dry period but not in early lactation. These data reflect impaired humoral immunity by heat stress in late gestation (do Amaral et al., 2011). In contrast, Lacetera et al. (2005) reported an increase in IgM secretion in PBMC isolated from cows that calved in summer relative to those that calved in spring after stimulation with pokeweed mitogen in vitro. These discrepancies between studies may reflect the differences in experimental design and evaluation methods (i.e., in vitro vs. in vivo).

Cytokine gene expression of PBMC collected from prepartum cooled and heat-stressed cows has also been examined. In contrast to responses in vitro, heat-stressed cows had greater TNF- $\alpha$ gene expression during the transition period and greater $I L-8$ gene expression in early lactation (Tao et al., 2013). Given the fact that inflammatory cytokines are related to the stress-induced acute-phase response in cattle (Petersen et al., 2004; Lomborg et al., 2008), an increase in inflammatory cytokine gene expression in lymphocytes of heat-stressed cows during the transition period probably reflects an adaptive response of cows under heat stress before calving and the carryover effect into early lactation. However, upon encountering a pathogen, immunological responses of noncooled heat-stressed cows may be suppressed compared with prepartum cooled cows (do Amaral et al., 2010).

The compromised immunological responses observed during the transition period following late-gestation heat stress may be due to altered PRL signaling in immune cells. Both innate and adaptive immune function are modulated via PRL signaling (Bole-Feysot et al., 1998; López-Meza et al., 2010) and PRL perturbations are associated with multiple autoimmune diseases (Orbach and Shoenfeld, 2007). In dairy calves, manipulation of PRL signaling through the inverse relationship between circulating PRL and PRLR gene expression in immune cells alters cellular immune function in vitro (Auchtung and Dahl, 2004a). Further, the enhanced PRL signaling in immune cells from cows under short day length during the dry period is associated with an increase in cellular immune function during the transition period (Auchtung et al., 2004b). Similarly, heat-stressed cows have increased circulating concentration of PRL and decreased $P R L R$ gene expression in lymphocytes during the transition period relative to those under heat stress abatement when dry (do Amaral et al., 2010). Therefore, altered PRL signaling may be partly responsible for the different immunological responses between prepartum heat-stressed and cooled cows during the transition period (do Amaral et al., 2010). An increase in blood cortisol level is observed in late-gestation cows calving under severe summer heat stress compared with those calving in cooler spring seasonal conditions and that increase in cortisol may factor into altered immune function observed under heat stress (Lacetera et al., 2005). However, in other controlled studies, cows heatstressed in the dry period have decreased (Stott, 1980) or similar (Tao et al., 2012a) circulating concentrations of cortisol relative to those under thermoneutrality or heat stress abatement. Thus, the role of cortisol in modulating immune function in heat-stressed dry cows is equivocal.

\section{Late-Gestation Heat Stress Effects on Reproduction}

It is well known that heat stress during lactation has detrimental effects on reproductive performance but studies related to the effect of late-gestation heat stress on reproduction in the next lactation are limited and the existing data are inconsistent. Comparison of cows dried in hot months (June, July, and August) versus cool months (December, January, and February) under commercial management in Florida revealed effects of season of the dry period on reproductive performance in the subsequent lactation (Thompson and Dahl, 2012). Indeed, cows dried in hot months had an increased number of breedings, days to first breeding, and days to pregnancy diagnosis during the first 150 DIM in the subsequent lactation relative to those dried in cool months. Although confounded with seasonal effects during lactation, these results may be partly explained by the carryover effects of ambient heat during the dry period on reproductive performance in the next lactation (Thompson and Dahl, 2012). However, studies conducted in Mississippi suggest that no correlation exists between late-gestation heat stress and reproductive performance in the next lactation (Moore et al., 1992; Avendaño-Reyes et al., 2010). Inconsistent reproductive responses after dry period cooling were also observed in controlled studies. For example, Avendaño-Reyes et al. (2006) reported that compared with those provided with cooling during the dry period, heat-stressed cows had more days open and increased services per conception in the subsequent lactation. In contrast, Adin et al. (2009) reported no differences with regard to reproductive traits between cows heat-stressed or cooled 
prepartum. Lewis et al. (1984) studied the residual effects of prepartum heat stress on uterine function and ovarian development in early lactation and found that late-gestation heat stress was related to increased systemic 13,14-dihydro-15-keto- $\mathrm{PGF}_{2 \alpha}$ concentrations, accelerated uterine involution, and smaller corpora lutea, but no differences were observed for days open and services per conception between treatments. However, one limitation of these controlled studies is the small sample size, which limits detection of significant differences regarding reproductive performance. A controlled study with a large number of animals is warranted to elucidate the effect of dry period heat stress on the reproduction in the next lactation.

\section{MATERNAL HEAT STRESS EFFECTS ON OFFSPRING}

In addition to substantial influence on the dam, maternal heat stress during late gestation also affects the fetus. Further, prenatal stress exerts carryover effects on the offspring in postnatal life. Related studies in dairy cattle are rare, but more data in other farm animals provide information and may be informative for dairy cattle.

\section{Fetal Thermogenesis and Thermoregulation}

Across many species under thermoneutral conditions, the fetus has a consistently higher body temperature relative to its dam (Laburn et al., 2000; Asakura, 2004). In sheep and goats during late gestation, fetal body temperature is approximately $0.6^{\circ} \mathrm{C}$ higher than maternal core body temperature (Laburn et al., 1992, 2002; Faurie et al., 2001). Data related to bovine fetal thermoregulation are limited; however, the higher rectal temperature $\left(\sim 39.5^{\circ} \mathrm{C}\right)$ of newborn calves at birth relative to mature cows (Vermorel et al., 1983) also suggests higher body temperature of the bovine fetus in utero compared with maternal temperature. Fetal thermoregulation is inhibited in utero and the body temperature of the fetus is dependent on fetal metabolic heat production and heat transfer with the dam. The fetus exchanges heat with the dam largely through the fetal-placental circulation, which accounts for approximately $85 \%$ of total fetal heat loss; the remaining heat is exchanged conductively through fetal membranes, amniotic fluid, and the uterine wall (Laburn et al., 2000; Asakura, 2004). In addition to heat exchange with the dam, the fetus has a 2-fold higher metabolic rate than the dam, which generates a large amount of heat and accounts for the higher body temperature (Schröder and Power, 1997; Laburn et al., 2000; Asakura, 2004). Moreover, the metabolic rate of the placenta is high and also contributes to the difference in body temperature between the dam and fetus (Schröder and Power, 1997; Asakura, 2004).

Under maternal heat stress, fetal body temperature increases as does maternal temperature, but the rate of the increase is slower than that of the dam (Laburn et al., 1992, 2002; Faurie et al., 2001). The smaller elevation in fetal body temperature may reflect the reduced fetal metabolic heat production that results from decreased uterine blood flow and oxygen delivery (Schröder and Power, 1997). Therefore, although not at the same rate as the maternal temperature, fetal body temperature still increases dramatically under maternal heat stress.

\section{Maternal Heat Stress Effects on Placental Functions}

Heat stress during gestation is associated with reduced placental weight (Collier et al., 1982b; Bell et al., 1989), which is related to a decrease in tissue size rather than the number of placentomes (Early et al., 1991). Compared with those from animals under thermoneutrality, the placenta from the hyperthermic animals had decreased total DNA, RNA, and protein content but concentrations were similar, which indicates that the reduced placenta mass is due to smaller cell number rather than cell size (Early et al., 1991). Additionally, decreased circulating placental hormones in heat-stressed animals [i.e., estrone sulfate (Collier et al. 1982a), placental lactogen (Bell et al. 1989), and pregnancy-associated glycoprotein (Thompson et al., 2013)] relative to those under thermoneutrality or heat stress abatement also reflect compromised placental development. Moreover, a decrease in total uterine and umbilical blood flow (Dreiling et al., 1991; Reynolds et al., 2006) and compromised placental vascularization (Regnault et al., 2003) are also observed in heatstressed animals.

It is tempting to expand the previously detailed observations and draw an analogy between mammary growth and placental development during late gestation. Heat stress during the dry period impairs both the mammary gland and placental development in late gestation. Indeed, both mammary gland and placenta present similarities of the compromised functions. For example, late-gestation heat stress decreases the total uterine (Dreiling et al., 1991; Reynolds et al., 2006) and mammary blood flow (Lough et al., 1990), which are associated with limits on uterine and mammary gland development. With the decreased mammary cell proliferation, the mammary gland of heat-stressed dry cows has a lower number of functional secretory cells at parturition (Tao et al., 2011), which is consistent with a smaller number of placental cells from hyperthermic 
animals (Early et al., 1991). Additionally, the linear relationship between calf birth weight and milk production of the dam (Collier et al., 1982b) also suggests the linkage between mammary gland and placental development in late gestation. Thus, in future studies with regard to effects of other management interventions during the dry period, such as photoperiod and nutrition, it is important to consider the effects on both mammary gland and placental development.

In pregnant animals, the oxygen and nutrient supply to the fetus rely on the placenta (Bell and Ehrhardt, 2002). With compromised placental growth and vascularization, it will be expected that placental oxygen and nutrient transfer to the fetus are also impaired under heat stress. Literature related to late-gestation heat stress on placental function is scarce; however, given the same endpoint (i.e., retarded fetal growth), the hyperthermia-induced placental insufficiency intrauterine growth retardation (PI-IUGR) sheep model provides some clues with regard to the maternal-fetal oxygen and nutrient exchange during heat stress (Morrison, 2008).

Maternal-fetal oxygen transport occurs by simple diffusion. Uterine blood flow, placental size, placental vascular resistance, and the maternal-fetal oxygen concentration gradient play deterministic roles in oxygen exchange (Reynolds et al., 2006; Yates et al., 2011). In the heat-stressed PI-IUGR sheep, the increased placental resistance due to impaired placental angiogenesis impedes transplacental oxygen diffusion (Regnault et al., 2003). However, with the increased maternal-fetal blood oxygen concentration gradient, the oxygen diffusion capacity per unit of placental mass in the PIIUGR sheep is actually similar to control ewes under thermoneutrality (Regnault et al., 2003). Collectively, the decreased placenta size in the hyperthermic animals determines that the total umbilical oxygen uptake is reduced and the fetus is exposed to a hypoxic state. Glucose is the primary energetic substrate in the fetus and placenta and fetal glucose is almost exclusively supplied by maternal circulation through the placenta under normal conditions (Bell and Ehrhardt, 2002; Hay, 2006). In contrast to simple oxygen diffusion, however, transplacental glucose transport in ruminants is mediated by facilitated diffusion through glucose transporters 1, 3, and 8 (Bell and Ehrhardt, 2002; Limesand et al., 2004; Hay, 2006). Therefore, maternalfetal glucose exchange is dependent on the maternalfetal glucose concentration gradient and the placental transport capacity (Bell and Ehrhardt, 2002; Hay, 2006). In addition to the decreased placenta size and surface area in PI-IUGR ewes, the glucose transport capacity per unit of placenta mass is also reduced (Bell and Ehrhardt, 2002; Limesand et al., 2004) because of the lower glucose transporter expression in placental tissue (Limesand et al., 2004; Yates et al., 2011). Even though the maternal-fetal glucose concentration gradient is increased in hyperthermic animals (Limesand et al., 2004), the impaired placental glucose transport capacity reduces the absolute total maternal-fetal glucose exchange (Bell and Ehrhardt, 2002; Hay, 2006; Yates et al., 2011). Because the concentration of most AA in fetal circulation is higher than in the dam, energydependent AA transporters are required in the placenta for active maternal-fetal AA transport to occur (Bell and Ehrhardt, 2002; Regnault et al., 2005). In PI-IUGR sheep, the transplacental transport of AA is impaired due to the reduced transport capacity that results from the smaller placental size and surface area and the compromised transport capacity per unit of placenta mass (de Vrijer et al., 2004; Regnault et al., 2005). Moreover, the reduced maternal concentrations of AA due to decreased feed intake in hyperthermic ewes may also affect maternal-fetal AA transport (de Vrijer et al., 2004) because reduced maternal circulating AA concentration also negatively affects transplacental AA transport (Regnault et al., 2005).

\section{Maternal Heat Stress Effects on Growth and Metabolism of Offspring During Pre- and Postpartum Periods}

Heat stress in late gestation decreases birth weight of newborn farm animals, which reflects compromised fetal development in utero (Table 1). The hyperthermia-related IUGR is a result of several factors. First, heat stress during gestation decreases gestation length (Table 1). In the last 2 mo of gestation in dairy cattle, the fetus grows at a rapid rate, which accounts for $60 \%$ of the total fetal body size at birth (Bauman and Currie, 1980). A reduction of several days in gestation length could account for a portion of the birth weight differences between calves from cows cooled versus heat-stressed during late gestation. As discussed previously, in response to maternal heat stress, an increase in fetal body temperature may also have a direct effect to retard fetal growth (Bell et al., 1989). However, data directly supporting this hypothesis are still lacking in cattle. A decrease in energy intake is a hallmark of the heat stress response in animals and malnutrition is a factor in reduced fetal growth (Wu et al., 2006). Severely restricted energy intake in the last trimester of beef cows dramatically decreases calf birth weight (Tudor, 1972); yet, a moderate decrease in energy intake in late gestation has no effect on calf birth weight (Hough et al., 1990; Janovick and Drackley, 2010). Additionally, fetal growth retardation related to maternal hyperthermia in late-gestation sheep is independent 
Table 1. Summary of studies on effects of late-gestation heat stress (HT) on gestation length and fetal/newborn weight in ruminants ${ }^{1}$

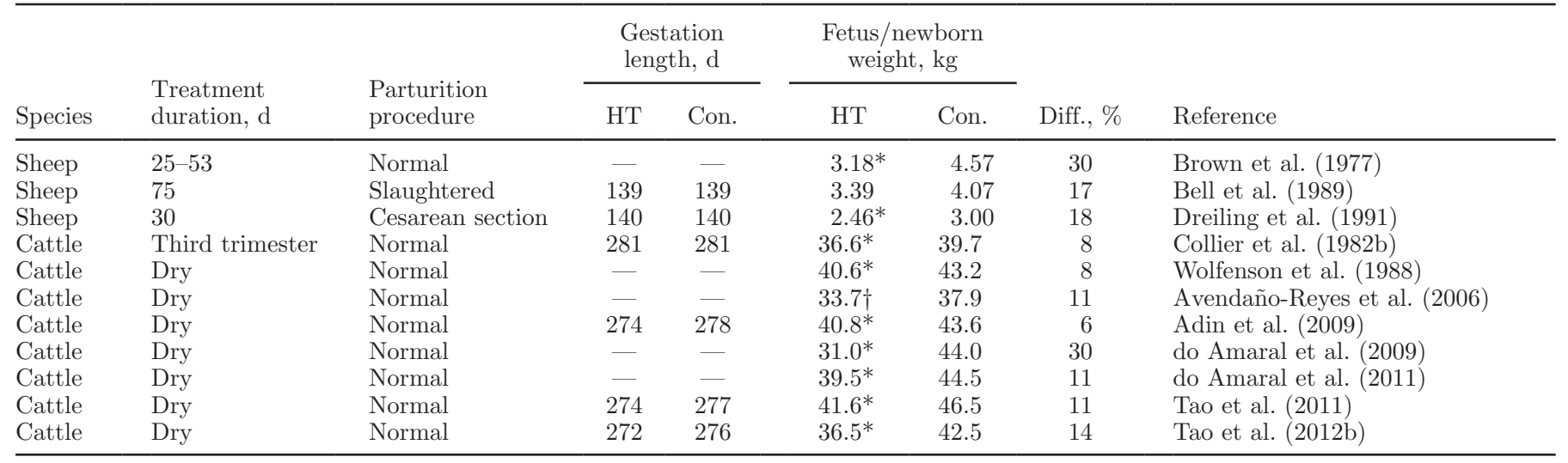

$* P<0.05 ; \dagger P<0.10$.

${ }^{1}$ Con. $=$ control; Diff. $=$ difference between treatments.

of maternal nutrition (Brown et al., 1977). Therefore, whether the small decrease in DMI of heat-stressed animals (10-15\%; do Amaral et al., 2009; Tao et al., 2011, $2012 \mathrm{~b}$ ) during late gestation plays an important role in compromised fetal growth is open to question.

Placental development and function are determinants of fetal growth. Maternal hyperthermia-related placental insufficiency is deleterious to fetal development and may also have profound effects on postnatal growth. In the PI-IUGR sheep model, in response to the hypoxia and nutrient restriction, the IUGR fetus develops a series of endocrine and metabolic adaptations that favor survival at the expense of growth. Compared with the normothermic controls, the IUGR sheep fetus has lower circulating glucose, insulin, and IGF-I (Limesand et al., 2005, 2006; Thorn et al., 2009) but increased catecholamine, epinephrine, and norepinephrine concentrations (Leos et al., 2010). In addition, heat stress impairs pancreatic $\beta$-cell growth (Limesand et al., 2005), compromises insulin synthesis and secretion (Limesand et al., 2006), and enhances insulin sensitivity at peripheral tissues (Limesand et al., 2006; Thorn et al., 2009). To cope with the decreased nutrient supply, the IUGR fetus stimulates hepatic gluconeogenesis and decreases the rate of whole-body glucose oxidation (Limesand et al., 2007). Under hypoxia, the anaerobic glucose metabolism in an IUGR fetus is enhanced and, thus, a large amount of lactate is produced (Limesand et al., 2007), which, together with increased circulating gluconeogenic AA (Limesand et al., 2006), serve as the substrates for hepatic gluconeogenesis. As a result, AA oxidation at peripheral tissues increases and, coupled with the decrease in placental AA transport and lower circulating IGF-I concentration, results in impaired protein accretion in the IUGR fetus (Thorn et al., 2009; Yates et al., 2011). Even though the hyperthermiainduced PI-IUGR sheep model encompasses early fetal development, whereas the cow model is applied later in gestation, using the same endpoints, such as shorter gestation length and lower birth weight (do Amaral et al., 2009; Chen et al., 2010), similar fetal endocrine and metabolic responses may be observed in the late-gestation heat-stressed cow. However, further studies are required to confirm the responses in the bovine model.

Fetal adaptations to heat stress in the IUGR model may also affect the postnatal growth of lambs. Relative to controls, the IUGR lamb has higher insulin response to glucose (Yates et al., 2011) and lower lipolytic response to adrenergic stimulation (Chen et al., 2010). Despite these metabolic differences, the overall postnatal growth rate is similar to normothermic control lambs (Chen et al., 2010). However, whether these metabolic responses in IUGR lambs induce changes in body composition, such as accelerated fat deposition, is unknown.

The altered metabolic response of offspring to maternal heat stress is also observed in dairy calves. The insulin response after colostrum ingestion was evaluated in newborn calves from cooled and noncooled heatstressed cows during the dry period. Newborn calves were fed $3.78 \mathrm{~L}$ of colostrum from their respective dams within $4 \mathrm{~h}$ after birth and serum samples were collected before colostrum feeding, 1, 4, and $7 \mathrm{~d}$ after birth to evaluate blood insulin concentration. Calves from both groups of cows had similar circulating insulin concentrations before colostrum feeding; however, those from noncooled heat-stressed dams had higher insulin concentrations relative to calves from cooled dams at $1 \mathrm{~d}$ after birth (Figure 4). Assuming similar colostral lactose concentration (Nardone et al., 1997), both groups of calves ingested similar amounts of lactose at birth. In other words, the increase in insulin response to colostrum ingestion in calves from noncooled heat-stressed dams is a result of enhanced pancreatic 
insulin secretion or impaired insulin clearance, or both, rather than an effect of diet. This result is consistent with hyperthermia-related IUGR lambs (Yates et al., 2011). Similar to the IUGR sheep model (Chen et al., 2010), both groups of calves have similar overall body growth rate during the prepubertal period (Tao et al., 2012a). But one has to be cautious in interpreting the growth variables of lambs and calves presented in both studies because of the small number of animals used in those experiments may limit detection of significant differences. Larger-scale studies with more animals are warranted to confirm or eliminate any carryover effect of maternal heat stress on the growth of offspring. Additionally, body composition was not examined in either study (Chen et al., 2010; Tao et al., 2012a). It is of interest, however, because it is the growth of the dairy heifer that may determine future performance and profitability of the farm. For example, increasing fat accumulation during the prepubertal period is negatively correlated with mammary parenchymal DNA at puberty and enhanced BCS at breeding is related to lower milk production in the first lactation (Silva et al., 2002). Whether similar shifts in body composition occur with in utero heat stress is currently unknown, but may reflect an area of management intervention to improve long-term productivity.

\section{Maternal Heat Stress Effects on Immune Function of Offspring}

In addition to the dramatic effects on fetal and neonatal growth, maternal heat stress also influences immune function of the offspring. Passive immunity is of particular importance to neonatal survival of farm animals and it is altered by maternal heat stress. When sows were exposed to heat stress during the last $2 \mathrm{wk}$ of gestation, their suckling piglets had lower circulating IgG concentrations compared with piglets from sows under thermoneutrality (Machado-Neto et al., 1987). A similar result was observed in dairy cattle, as after ingestion of the same amount of colostrum from their respective dams, calves from heat-stressed cows that were not cooled during the dry period had lower serum IgG concentration and apparent efficiency of absorption relative to those from cooled dams (Tao et al., 2012a). When feeding pooled colostrum to newborn calves, those from heat-stressed dams only had slightly lower blood IgG concentration compared with calves from cooled dams (Stott, 1980). However, that author attributed the compromised IgG transfer of calves from heat-stressed cows to the direct effect of thermal stress on neonates at birth and for a short period after birth rather than chronic maternal heat stress. Mechanisms whereby passive immunity is impaired by maternal heat stress are still unknown but may relate to either colostral or animal effects, or both. Exposure to heat stress during late gestation in sows results in an increase in cortisol concentrations in dams and piglets (Machado-Neto et al., 1987), which is a possible physiological reason for accelerated enterocyte maturation and decreased colostral IgG absorption of piglets heatstressed in utero (Machado-Neto et al., 1987; Merlot et al., 2008). However, when pregnant sows were exposed to cold stress during late gestation, maternal circulating cortisol was also elevated but piglets had higher serum IgG concentrations compared with those from dams under thermoneutrality (Bate and Hacker, 1985). In late-gestation ruminants, heat-stressed dams actually have decreased (Stott, 1980; Bell et al., 1989) or similar (Tao et al., 2012a) circulating concentrations of cortisol relative to those under thermoneutrality or heat stress abatement. Moreover, the lower serum cortisol concentration in newborn calves from heat-stressed dairy cows at birth compared with those from cooled animals (Tao et al., 2012a) suggests that blood cortisol concentration may not be a proper explanation for the impaired passive immunity due to prenatal heat stress. It is suggested that $\mathrm{Fc}$ receptor expression and cell apoptosis of enterocytes and intestinal epithelial cells play roles in the passive immunity of ruminant newborns (Mayer et al., 2002; Castro-Alonso et al., 2008), but it is unknown if maternal heat stress alters these properties. Thus, more studies are necessary to elucidate the mechanism underlying compromised passive immunity in calves following late-gestation heat stress.

One of the determining factors of passive immunity is colostral Ig content (Quigley and Drewry, 1998). Dairy heifers exposed to heat stress in the last $3 \mathrm{wk}$ of gesta-

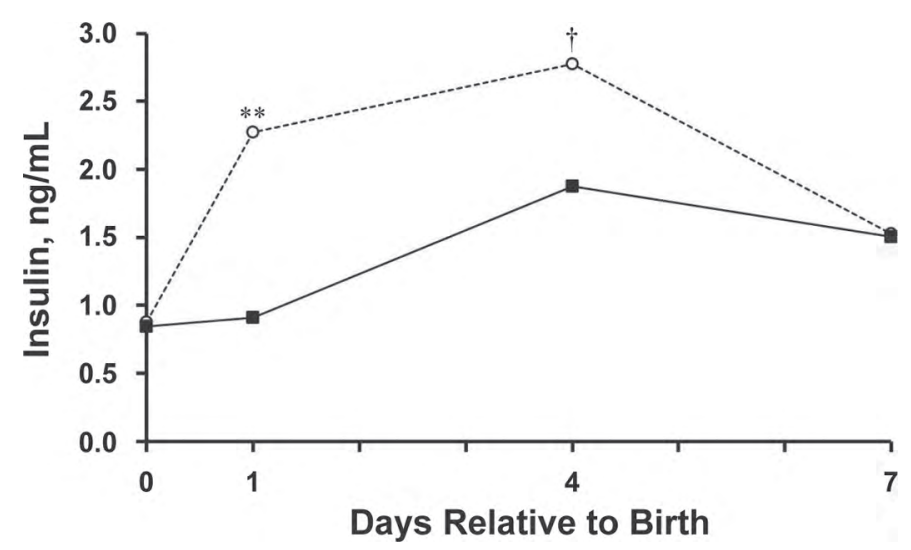

Figure 4. Effect of heat stress and cooling during the dry period on serum insulin concentrations of calves during the first $7 \mathrm{~d}$ of life. Solid squares ( $\mathbf{\square})$ represent calves from cows exposed to cooling during the dry period and open circles $(O)$ represent those from cows in heat stress. Effect of treatment: $P=0.01$, time: $P<0.01$, and treatment by time interaction: $P=0.01$. ${ }^{* *} P<0.01 ; \dagger P<0.10$. 
tion produce less Ig in the colostrum compared with their counterparts under thermoneutrality (Nardone et al., 1997). In contrast, relative to cooling, dry period heat stress has no effect on the volume and Ig content of the colostrum in cows (Tao et al., 2012a). Additionally, colostrum contains numerous growth factors, immune components, and hormones in addition to Ig and different colostral components may affect IgG transfer in the intestinal tract of neonates (Sangild, 2003). For example, feeding colostrum from dams that are nutrient restricted in late gestation compromises passive immunity in newborn calves (Hough et al., 1990) but enhances the Ig transfer in neonatal lambs (Hodgson et al., 1997). In addition, bovine colostrum is used as a supplement in heavily exercised athletes to improve intestinal integrity and prevent gut permeability (Marchbank et al., 2011). Therefore, the differing colostrum composition that follows maternal heat stress may also account for some of the decreased passive immune transfer observed in farm animals and related studies in dairy cattle are under investigation in our laboratory.

But passive transfer may not be the only aspect of immune function altered by prenatal heat stress, as prenatal stressors can modify $\mathrm{T}$ - and B-cell function of the offspring (Merlot et al., 2008). For example, prenatal social stress in pregnant sows increases the in vitro lymphocyte proliferative response to a mitogen in piglets in early life (Couret et al., 2009). However, data related to the maternal heat stress and immune function in farm animals is scarce. Tao et al. (2012a) evaluated effects of maternal heat stress on the adaptive immune function of calves during the preweaned period by the PBMC proliferation assay ex vivo and ovalbumin challenge in vivo. Compared with calves from cooled cows, those from noncooled dry cows had lower PBMC proliferation rate, which indicates impaired lymphocyte function after prenatal heat stress. However, the antiovalbumin $\mathrm{Ab}$ production was not different between treatments, which suggests that prenatal heat stress did not influence B-cell function during early life of the calf. Thus, in addition to passive immunity, the cellmediated arm of immune function is also compromised by late-gestation heat stress.

Cellular mechanisms that induce altered immune function in offspring after late-gestation heat stress are still unknown. Preliminary data indicate that relative to newborn calves from noncooled cows, those from cooled cows during the dry period tend to have lower thymus weight after adjustment for BW [S. Tao, A. P. A. Monteiro, S. E. Johnson, A. D. Ealy, and G. E. Dahl, all from University of Florida (Gainesville), unpublished data]. These data suggest that maternal hyperthermia during late gestation affects development of a primary lymphoid organ in utero. In addition to or- gan weight, the immune cell population of the thymus of calves may also be altered by maternal hyperthermia in utero, which probably contributes to the impaired PBMC proliferation. The ileal Peyer's patch is the primary lymphoid organ for B-lymphocyte development in cattle from late gestation into the neonatal period and may also be influenced by hyperthermia in utero (Yasuda et al., 2006). Thus, further studies with regard to morphology, function, and immune cell population of primary lymphoid organs in the fetal and neonatal calves from cooled or heat-stressed cows during the dry period are also needed to better understand fetal immune organ reprogramming by environmental insults in utero.

\section{CONCLUSIONS}

The impact of the environment on dry cow health and future productivity is significant, both on the dam and offspring. Although heat stress has tremendous effect on production, health, and reproduction in lactating dairy cows, the thermal status of nonlactating dry cows has been largely ignored as a biological question, and even more so from a management standpoint. The preceding discussion provides evidence that heat stress during late gestation has profound effects on cows during the pre- and postpartum periods. In addition to impaired immune function during the transition period, heat stress during the dry period adversely affects mammary gland development before parturition and exerts residual effects on metabolism in early lactation and subsequent lactational performance. Maternal heat stress in late gestation also compromises placental development and fetal growth and negatively affects the immune competence of the offspring. These observations suggest the importance of heat stress abatement as an easily implemented, noninvasive method for managers to improve dry cow performance and calf health and growth.

\section{REFERENCES}

Adin, G., A. Gelman, R. Solomon, I. Flamenbaum, M. Nikbachat, E. Yosef, A. Zenou, A. Shamay, Y. Feuermann, S. J. Mabjeesh, and J. Miron. 2009. Effects of cooling dry cows under heat load conditions on mammary gland enzymatic activity, intake of food water, and performance during the dry period and after parturition. Livest. Sci. 124:189-195.

Asakura, H. 2004. Fetal and neonatal thermoregulation. J. Nippon Med. Sch. 71:360-370.

Auchtung, T. L., and G. E. Dahl. 2004a. Prolactin mediates photoperiodic immune enhancement: Effects of administration of exogenous prolactin on circulating concentrations, receptor expression, and immune function in steers. Biol. Reprod. 71:1913-1918.

Auchtung, T. L., A. G. Rius, P. E. Kendall, T. B. McFadden, and G. E. Dahl. 2005. Effects of photoperiod during the dry period on prolactin, prolactin receptor, and milk production of dairy cows. J. Dairy Sci. 88:121-127. 
Auchtung, T. L., J. L. Salak-Johnson, D. E. Morin, C. C. Mallard, and G. E. Dahl. 2004b. Effects of photoperiod during the dry period on cellular immune function of dairy cows. J. Dairy Sci. 87:3683-3689.

Avendaño-Reyes, L., F. D. Alvarez-Valenzuela, A. Correa-Calderón, J. S. Saucedo-Quintero, P. H. Robinson, and J. G. Fadel. 2006. Effect of cooling Holstein cows during the dry period on postpartum performance under heat stress conditions. Livest. Sci. 281:2535-2547.

Avendaño-Reyes, L., J. W. Fuquay, R. B. Moore, Z. Liu, B. L. Clark, and C. Vierhout. 2010. Relationship between accumulated heat stress during the dry period, body condition score, and reproduction parameters of Holstein cows in tropical condition. Trop. Anim. Health Prod. 42:265-273.

Bachman, K. C., and M. L. Schairer. 2003. Bovine studies on optimal lengths of dry period. J. Dairy Sci. 86:3027-3037.

Bate, L. A., and R. R. Hacker. 1985. Influence of environmental temperature during late gestation and soon after birth on IgG absorption by newborn piglets. Can. J. Anim. Sci. 65:87-93.

Bauman, D. E. 2000. Regulation of nutrient partitioning during lactation: Homeostasis and homeorhesis revisited. Pages 311-328 in Ruminant Physiology: Digestion, Metabolism, Growth and Reproduction. P. B. Cronjé, ed. CABI Publishing, Wallingford, UK.

Bauman, D. E., and W. B. Currie. 1980. Partitioning of nutrients during pregnancy and lactation: A review of mechanisms involving homeostasis and homeorhesis. J. Dairy Sci. 63:1514-1529.

Baumgard, L. H., J. B. Wheelock, S. R. Sanders, C. E. Moore, H. B. Green, M. R. Waldron, and R. P. Rhoads. 2011. Postabsorptive carbohydrate adaptations to heat stress and monensin supplementation in lactating Holstein cows. J. Dairy Sci. 94:5620-5633.

Beardsley, G. L., L. D. Muller, H. A. Garverick, F. C. Ludens, and W. L. Tucker. 1976. Initiation of parturition in dairy cows with dexamethasone. II. Response to dexamethasone in combination with estradiol benzoate. J. Dairy Sci. 59:241-247.

Bell, A. W. 1995. Regulation of organic nutrient metabolism during transition from late pregnancy to early lactation. J. Anim. Sci. 73:2804-2819.

Bell, A. W., and R. A. Ehrhardt. 2002. Regulation of placental nutrient transport and implications for fetal growth. Nutr. Res. Rev. $15: 211-230$.

Bell, A. W., B. W. McBride, R. Slepetis, R. J. Early, and W. B. Currie. 1989. Chronic heat stress and prenatal development in sheep: I. Conceptus growth and maternal plasma hormones and metabolites. J. Anim. Sci. 67:3289-3299.

Bernabucci, U., N. Lacetera, L. H. Baumgard, R. P. Rhoads, B. Ronchi, and A. Nardone. 2010. Metabolic and hormonal acclimation to heat stress in domesticated ruminants. Animal 4:1167-1183.

Bole-Feysot, C., V. Goffin, M. Edery, N. Binart, and P. A. Kelly. 1998. Prolactin (PRL) and its receptor: Actions, signal transduction pathways and phenotypes observed in PRL receptor knockout mice. Endocr. Rev. 19:225-268.

Bremmer, D. R., J. O. Christensen, R. R. Grummer, F. E. Rasmussen, and M. C. Wiltbank. 1999. Effects of induced parturition and estradiol on feed intake, liver triglyceride concentration, and plasma metabolites of transition dairy cows. J. Dairy Sci. 82:1440-1448.

Brown, D. E., P. C. Harrison, F. C. Hinds, J. A. Lewis, and M. H. Wallace. 1977. Heat stress effects on fetal development during late gestation in the ewe. J. Anim. Sci. 44:442-446.

Capuco, A. V., R. M. Akers, and J. J. Smith. 1997. Mammary growth in Holstein cows during the dry period: Quantification of nucleic acids and histology. J. Dairy Sci. 80:477-487.

Capuco, A. V., S. E. Ellis, S. A. Hale, E. Long, R. A. Erdman, X. Zhao, and M. J. Paape. 2003. Lactation persistency: Insights from mammary cell proliferation studies. J. Anim. Sci. 81:18-31.

Castro-Alonso, A., N. Castro, J. Capote, A. Morales-delaNuez, I. Moreno-Indias, D. Sánchez-Macias, P. Herraez, and A. Argüello. 2008. Short communication: Apoptosis regulates passive immune transfer in newborn kids. J. Dairy Sci. 91:2086-2088.

Chen, X., A. L. Fahy, A. S. Green, M. J. Anderson, R. P. Rhoads, and S. W. Limesand. 2010. 32 -Adrenergic receptor desensitization in perirenal adipose tissue in fetuses and lambs with placental insufficiency-induced intrauterine growth restriction. J. Physiol. 588:3539-3549.

Collier, R. J., D. K. Beede, W. W. Thatcher, L. A. Israel, and C. J. Wilcox. 1982a. Influences of environment and its modification on dairy animal health and production. J. Dairy Sci. 65:2213-2227.

Collier, R. J., J. L. Collier, R. P. Rhoads, and L. H. Baumgard. 2008. Invited review: Genes involved in the bovine heat stress response. J. Dairy Sci. 91:445-454.

Collier, R. J., G. E. Dahl, and M. J. VanBaale. 2006. Major advances associated with environmental effects on dairy cattle. J. Dairy Sci. 89:1244-1253.

Collier, R. J., S. G. Doelger, H. H. Head, W. W. Thatcher, and C. J. Wilcox. 1982b. Effects of heat stress during pregnancy on maternal hormone concentrations, calf birth weight and postpartum milk yield of Holstein cows. J. Anim. Sci. 54:309-319.

Couret, D., A. Jamin, G. Kuntz-Simon, A. Prunier, and E. Merlot. 2009. Maternal stress during late gestation has moderate but longlasting effects on the immune system of the piglets. Vet. Immunol. Immunopathol. 131:17-24.

Dahl, G. E. 2008. Effects of short day photoperiod on prolactin signaling in dry cows: A common mechanism among tissues and environments. J. Anim. Sci. 86:10-14.

Dahl, G. E., and D. Petitclerc. 2003. Management of photoperiod in the dairy herd for improved production and health. J. Anim. Sci. 81(Suppl. 3):11-17.

Dahl, G. E., S. Tao, and I. M. Thompson. 2012. Lactation Biology Symposium: Effects of photoperiod on mammary gland development and lactation. J. Anim. Sci. 90:755-760.

de Vrijer, B., T. R. H. Regnault, R. B. Wilkening, G. Meschia, and F. C. Battaglia. 2004. Placental uptake and transport of ACP, a neutral nonmetabolizable amino acid, in an ovine model of fetal growth restriction. Am. J. Physiol. Endocrinol. Metab. 287:E1114-E1124.

do Amaral, B. C., E. E. Connor, S. Tao, M. J. Hayen, J. W. Bubolz, and G. E. Dahl. 2009. Heat-stress abatement during the dry period: Does cooling improve transition into lactation? J. Dairy Sci. 92:5988-5999.

do Amaral, B. C., E. E. Connor, S. Tao, M. J. Hayen, J. W. Bubolz, and G. E. Dahl. 2010. Heat stress abatement during the dry period influences prolactin signaling in lymphocytes. Domest. Anim. Endocrinol. 38:38-45.

do Amaral, B. C., E. E. Connor, S. Tao, M. J. Hayen, J. W. Bubolz, and G. E. Dahl. 2011. Heat stress abatement during the dry period influences metabolic gene expression and improves immune status in the transition period of dairy cows. J. Dairy Sci. 94:86-96.

Drackley, J. K. 1999. Biology of dairy cows during the transition period: The final frontier? J. Dairy Sci. 82:2259-2273.

Drackley, J. K., T. R. Overton, and G. N. Douglas. 2001. Adaptations of glucose and long-chain fatty acid metabolism in liver of dairy cows during the periparturient period. J. Dairy Sci. 84(E. Suppl.):E100-E112

Dreiling, C. E., F. S. Carman III, and D. E. Brown. 1991. Maternal endocrine and fetal metabolic responses to heat stress. J. Dairy Sci. 74:312-327.

Early, R. J., B. W. McBride, I. Vatnick, and A. W. Bell. 1991. Chronic heat stress and prenatal development in sheep: II. Placental cellularity and metabolism. J. Anim. Sci. 69:3610-3616.

Etherton, T. D., and D. E. Bauman. 1998. Biology of somatotropin in growth and lactation of domestic animals. Physiol. Rev. 78:745761

Faurie, A. S., D. Mitchell, and H. P. Laburn. 2001. Feto-maternal relationships in goats during heat and cold exposure. Exp. Physiol. 86:199-204.

Fuquay, J. W. 1981. Heat stress as it affects animal production. J. Anim. Sci. 52:164-174.

Goff, J. P., and R. L. Horst. 1997. Physiological changes at parturition and their relationship to metabolic disorders. J. Dairy Sci. 80:1260-1268.

Grummer, R. R., and R. R. Rastani. 2004. Why reevaluate dry period length? J. Dairy Sci. 87(E. Suppl.):E77-E85. 
Hahn, G. L. 1999. Dynamic responses of cattle to thermal heat loads. J. Anim. Sci. 77:10-20.

Hay, W. W., Jr. 2006. Placental-fetal glucose exchange and fetal glucose metabolism. Trans. Am. Clin. Climatol. Assoc. 117:321-340.

Hayirli, A. 2006. The role of exogenous insulin in the complex of hepatic lipidosis and ketosis associated with insulin resistance phenomenon in postpartum dairy cattle. Vet. Res. Commun. 30:749-774.

Hodgson, J. C., S. M. Rhind, and D. J. Flint. 1997. Influence of maternal nutrition and stress on gut permeability to immunoglobulin in newborn lambs. Biochem. Soc. Trans. 25:339S.

Hough, R. L., F. D. McCarthy, H. D. Kent, D. E. Eversole, and M L. Wahlberg. 1990. Influence of nutritional restriction during late gestation on production measures and passive immunity in beef cattle. J. Anim. Sci. 68:2622-2627.

Janovick, N. A., and J. K. Drackley. 2010. Prepartum dietary management of energy intake affects postpartum intake and lactation performance by primiparous and multiparous Holstein cows. J. Dairy Sci. 93:3086-3102.

Kadzere, C. T., M. R. Murphy, N. Silaninove, and E. Maltz. 2002. Heat stress in lactating dairy cows: A review. Livest. Prod. Sci. 77:59-91.

Kahn, C. R. 1978. Insulin resistance, insulin insensitivity, and insulin unresponsiveness: A necessary distinction. Metabolism 27:18931902.

Kim, K. H. H., D.-H. Kim, Y.-K. Oh, S.-S. Lee, H.-J. Lee, D.-W. Kim, Y.-J. Seol, and N. Kimura. 2010. Productivity and energy partition of late lactation dairy cows during heat exposure. Anim. Sci. J. $81: 58-62$.

Kregel, K. C. 2002. Invited review: Heat shock proteins: Modifying factors in physiological stress responses and acquired thermotolerance. J. Appl. Physiol. 92:2177-2186.

Laburn, H., A. Faurie, and D. Mitchell. 2000. The thermal physiology of the ruminant fetus. Pages 295-310 in Ruminant Physiology: Digestion, Metabolism, Growth and Reproduction. P. B. Cronjé, ed. CABI Publishing, Wallingford, UK.

Laburn, H. P., A. Faurie, K. Goelst, and D. Mitchell. 2002. Effects on fetal and maternal body temperatures of exposure of pregnant ewes to heat, cold, and exercise. J. Appl. Physiol. 92:802-808.

Laburn, H. P., D. Mitchell, and K. Goelst. 1992. Fetal and maternal body temperatures measured by radiotelemetry in near-term sheep during thermal stress. J. Appl. Physiol. 72:894-900.

Lacetera, N., U. Bernabucci, B. Ronchi, D. Scalia, and A. Nardone. 2002. Moderate summer heat stress does not modify immunological parameters of Holstein dairy cows. Int. J. Biometeorol. 46:33-37.

Lacetera, N., U. Bernabucci, D. Scalia, B. Ronchi, G. Kuzminsky, and A. Nardone. 2005. Lymphocyte functions in dairy cows in hot environment. Int. J. Biometeorol. 50:105-110.

Lanneau, D., A. de Thonel, S. Maurel, C. Didelot, and C. Garrido. 2007. Apoptosis versus cell differentiation: Role of heat shock protein HSP90, HSP70 and HSP27. Prion 1:53-60.

Leos, R. A., M. J. Anderson, X. Chen, J. Pugmire, K. A. Anderson, and S. W. Limesand. 2010. Chronic exposure to elevated norepinephrine suppresses insulin secretion in fetal sheep with placental insufficiency and intrauterine growth restriction. Am. J. Physiol. Endocrinol. Metab. 298:E770-E778.

Lewis, G. S., W. W. Thatcher, E. L. Bliss, M. Drost, and R. J. Collier. 1984. Effects of heat stress during pregnancy on postpartum reproductive changes in Holstein cows. J. Anim. Sci. 58:174-186.

Limesand, S. W., J. Jensen, J. C. Hutton, and W. W. Hay Jr. 2005. Diminished $\beta$-cell replication contributes to reduced $\beta$-cell mass in fetal sheep with intrauterine growth restriction. Am. J. Physiol. Regul. Integr. Comp. Physiol. 288:R1297-R1305.

Limesand, S. W., T. R. Regnault, and W. W. Hay Jr. 2004. Characterization of glucose transporter 8 (GLUT8) in the ovine placenta of normal and growth restricted fetuses. Placenta 25:70-77.

Limesand, S. W., P. J. Rozance, D. Smith, and W. W. Hay Jr. 2007. Increased insulin sensitivity and maintenance of glucose utilization rates in fetal sheep with placental insufficiency and intrauterine growth restriction. Am. J. Physiol. Endocrinol. Metab. 293:E1716-E1725.
Limesand, S. W., P. J. Rozance, G. O. Zerbe, J. C. Hutton, and W. W. Hay Jr. 2006. Attenuated insulin release and storage in fetal sheep pancreatic islets with intrauterine growth restriction. Endocrinology 147:1488-1497.

Lomborg, S. R., L. R. Nielsen, P. M. H. Heegaard, and S. Jacobsen. 2008. Acute phase protein in cattle after exposure to complex stress. Vet. Res. Commun. 32:575-582.

López-Meza, J. E., L. Lara-Zárate, and A. Ochoa-Zarzosa. 2010. Effects of prolactin on innate immunity of infectious disease. Open Neuroendocrinol. J. 3:175-179.

Lough, D. S., D. L. Beede, and C. J. Wilcox. 1990. Effects of feed intake and thermal stress on mammary blood flow and other physiological measurements in lactating dairy cows. J. Dairy Sci. 73:325-332.

Machado-Neto, R., C. N. Graves, and S. E. Curtis. 1987. Immunoglobulins in piglets from sows heat-stressed prepartum. J. Anim. Sci. 65:445-455.

Mallard, B. A., J. C. Dekkers, M. J. Ireland, K. E. Leslie, S. Sharif, C. Lacey Vankampen, L. Wagter, and B. N. Wilkie. 1998. Alteration in immune responsiveness during the peripartum period and its ramification on dairy cow and calf health. J. Dairy Sci $81: 585-595$

Marchbank, T., G. Davison, J. R. Oakes, M. A. Ghatei, M. Patterson, M. P. Moyer, and R. J. Playford. 2011. The nutriceutical bovine colostrum truncates the increase in gut permeability caused by heavy exercise in athletes. Am. J. Physiol. Gastrointest. Liver Physiol. 300:G477-G484.

Mayer, B., A. Zolnai, L. V. Frenyó, V. Jancsik, Z. Szentirmay, L. Hammarström, and I. Kacskovics. 2002. Redistribution of the sheep neonatal Fc receptor in the mammary gland around the time of parturition in ewes and its localization in the small intestine of neonatal lambs. Immunology 107:288-296.

Merlot, E., D. Couret, and W. Otten. 2008. Prenatal stress, fetal imprinting and immunity. Brain Behav. Immun. 22:42-51.

Moore, R. B., J. W. Fuquay, and W. J. Drapala. 1992. Effects of late gestation heat stress on postpartum milk production and reproduction in dairy cattle. J. Dairy Sci. 75:1877-1882.

Morrison, J. L. 2008. Sheep models of intrauterine growth restriction: Fetal adaptations and consequences. Clin. Exp. Pharmacol Physiol. 35:730-743.

Nardone, A., N. Lacetera, U. Bernabucci, and B. Ronchi. 1997. Composition of colostrum from dairy heifers exposed to high air temperatures during late pregnancy and the early postpartum period. J. Dairy Sci. 80:838-844.

NRC. 2001. Nutrient Requirements of Dairy Cattle. 7th rev. ed. Nat. Acad. Press, Washington, DC.

Orbach, H., and Y. Shoenfeld. 2007. Hyperprolactinemia and autoimmune diseases. Autoimmun. Rev. 6:537-542.

Petersen, H. H., J. P. Nielsen, and P. M. H. Heegaard. 2004. Application of acute phase protein measurements in veterinary clinical chemistry. Vet. Res. 35:163-187.

Quigley, J. D., III, and J. J. Drewry. 1998. Nutrient and immunity transfer from cow to calf pre- and postcalving. J. Dairy Sci 81:2779-2790.

Regnault, T. R. H., B. de Vrijer, H. L. Galan, M. L. Davidsen, K. A. Trembler, F. C. Battaglia, R. B. Wilkening, and R. V. Anthony. 2003. The relationship between transplacental $\mathrm{O}_{2}$ diffusion and placental expression of PIGF, VEGF and their receptors in a placental insufficiency model of fetal growth restriction. J. Physiol. 550:641-656.

Regnault, T. R. H., J. E. Friedman, R. B. Wilkening, R. V. Anthony, and W. W. Hay, Jr. 2005. Fetoplacental transport and utilization of amino acids in IUGR - A review. Placenta 26(Suppl. A):S52S62.

Reynolds, L. P., J. S. Caton, D. A. Redmer, A. T. Grazul-Bilska, K. A. Vonnahme, P. P. Borowicz, J. S. Luther, J. M. Wallace, G. Wu, and T. E. Spencer. 2006. Evidence for altered placental blood flow and vascularity in compromised pregnancies. J. Physiol. 572:51-58.

Rhoads, M. L.. J. W. Kim, R. J. Collier, B. A. Crooker, Y. R. Boisclair, L. H. Baumgard, and R. P. Rhoads. 2010. Effects of heat 
stress and nutrition on lactating Holstein cows: II. Aspects of hepatic growth hormone responsiveness. J. Dairy Sci. 93:170-179.

Sangild, P. T. 2003. Uptake of colostral immunoglobulins by the compromised newborn farm animals. Acta Vet. Scand. Suppl. 98:105-122.

Schmitt, D., H. A. Garverick, E. C. Mather, J. D. Sikes, B. N. Day, and R. E. Erb. 1975. Induction of parturition in dairy cattle with dexamethasone and estradiol benzoate. J. Anim. Sci. 40:261-268.

Schröder, H. J., and G. G. Power. 1997. Engine and radiator: Fetal and placental interactions for heat dissipation. Exp. Physiol. 82:403-414.

Silva, L. F. P., M. J. VandeHaar, B. K. Whitlock, R. P. Radcliff, and H. A. Tucker. 2002. Short communication: Relationship between body growth and mammary development in dairy heifers. J. Dairy Sci. $85: 2600-2602$.

Sorensen, M. T., J. V. Nørgaard, P. K. Theil, M. Vestergaard, and K. Sejrsen. 2006. Cell turnover and activity in mammary tissue during lactation and dry period in dairy cows. J. Dairy Sci. 89:46324639.

Stott, G. H. 1980. Immunoglobulin absorption in calf neonates with special considerations of stress. J. Dairy Sci. 63:681-688.

Tao, S., J. W. Bubolz, B. C. do Amaral, I. M. Thompson, M. J. Hayen, S. E. Johnson, and G. E. Dahl. 2011. Effect of heat stress during the dry period on mammary gland development. J. Dairy Sci. 94:5976-5986.

Tao, S., E. E. Connor, J. W. Bubolz, I. M. Thompson, B. C. do Amaral, M. J. Hayen, and G. E. Dahl. 2013. Short communication: Effect of heat stress during the dry period on gene expression of mammary tissue and peripheral blood mononuclear cells. J. Dairy Sci. 96:378-383.

Tao, S., A. P. Monteiro, I. M. Thompson, M. J. Hayen, and G. E. Dahl. 2012a. Effect of late-gestation maternal heat stress on growth and immune function of dairy calves. J. Dairy Sci. 95:7128-7136.

Tao, S., I. M. Thompson, A. P. A. Monteiro, M. J. Hayen, L. J. Young, and G. E. Dahl. 2012b. Effect of cooling heat-stressed dairy cows during the dry period on insulin response. J. Dairy Sci. 95:50355046 .

Tarazón-Herrera, M., J. T. Huber, J. Santos, H. Mena, L. Nusso, and C. Nussio. 1999. Effects of bovine somatotropin and evaporative cooling plus shade on lactation performance of cows during summer heat stress. J. Dairy Sci. 82:2352-2357.

Thompson, I. M., and G. E. Dahl. 2012. Dry period seasonal effects on the subsequent lactation. Prof. Anim. Sci. 28:628-631.

Thompson, I. M., S. Tao, J. Branen, A. D. Ealy, and G. E. Dahl. 2013. Environmental regulation of pregnancy-specific protein B concentrations during late pregnancy in dairy cattle. J. Anim. Sci. 91:168-173.

Thompson, I. M., S. Tao, K. C. Jeong, W. W. Thatcher, and G. E. Dahl. 2012. Effect of cooling during the dry period on neutrophil gene expression after Streptococcus uberis infection. J. Anim. Sci. 90(Suppl. 3):188 (Abstr.)

Thorn, S. R., T. R. H. Regnault, L. D. Brown, P. J. Rozance, J. Keng, M. Roper, R. B. Wilkening, W. W. Hay Jr., and J. E. Friedman. 2009. Intrauterine growth restriction increases fetal hepatic gluconeogenic capacity and reduces messenger ribonucleic acid translation initiation and nutrient sensing in fetal liver and skeletal muscle. Endocrinology 150:3021-3030.

Tucker, H. A. 2000. Hormones, mammary growth, and lactation: A 41-year perspective. J. Dairy Sci. 83:874-884.

Tudor, G. D. 1972. The effect of pre- and post-natal nutrition on the growth of beef cattle. 1 . The effect of nutrition and parity of the dam on calf birth weight. Aust. J. Agric. Res. 23:389-395.

Urdaz, J. H., M. W. Overton, D. A. Moore, and J. E. P. Santos. 2006. Technical note: Effects of adding shade and fans to a feedbunk sprinkler system for preparturient cows on health and performance. J. Dairy Sci. 89:2000-2006.

USDA-NASS (United States Department of Agriculture-National Agricultural Statistics Service). 2011. Florida livestock, dairy and poultry summary 2010. USDA-NASS, Washington, DC.

Vermorel, M., C. Dardillat, J. Vernet, Saido, and C. Demigne. 1983. Energy metabolism and thermoregulation in the newborn calf. Ann. Rech. Vet. 14:382-389.

Vernon, R. G., and G. M. Pond. 1997. Adaptations of maternal adipose tissue to lactation. J. Mammary Gland Biol. Neoplasia 2:231-241.

Wall, E. H., T. L. Auchtung, G. E. Dahl, S. E. Ellis, and T. B. McFadden. 2005. Exposure to short day photoperiod during the dry period enhances mammary growth in dairy cows. J. Dairy Sci. 88:1994-2003

West, J. W. 2003. Effects of heat-stress on production in dairy cattle. J. Dairy Sci. 86:2131-2144.

Wheelock, J. B., R. P. Rhoads, M. J. VanBaale, S. R. Sanders, and L. H. Baumgard. 2010. Effects of heat stress on energetic metabolism in lactating Holstein cows. J. Dairy Sci. 93:644-655.

Wolfenson, D., I. Flamenbaum, and A. Berman. 1988. Dry period heat stress relief effects on prepartum progesterone, calf birth weight, and milk production. J. Dairy Sci. 71:809-818.

Wu, G., F. W. Bazer, J. M. Wallace, and T. E. Spencer. 2006. BoardInvited Review: Intrauterine growth retardation: Implications for the animal sciences. J. Anim. Sci. 84:2316-2337.

Yasuda, M., C. N. Jenne, L. J. Kennedy, and J. D. Reynolds. 2006. The sheep and cattle Peyer's patch as a site of B-cell development. Vet. Res. 37:401-415.

Yates, D. T., A. S. Green, and S. W. Limesand. 2011. Catecholamines mediate multiple fetal adaptations during placental insufficiency that contribute to intrauterine growth restriction: Lessons from hyperthermic sheep. J. Pregnancy 2011:740408. 